\title{
Correction to: The interaction of crime \& place: an exploratory study of crime \& policing in non-metropolitan areas
}

\section{Rashi K. Shukla ${ }^{1} \cdot$ Danielle Stoneberg $^{2} \cdot$ Kenzi Lockwood $^{1} \cdot$ Paige Copple $^{1}$. Amanda Dorman ${ }^{1}$. F. Matt Jones ${ }^{1}$}

Published online: 8 July 2019

(c) Springer Nature Limited 2019

\section{Correction to: Crime Prevention and Community Safety https://doi.org/10.1057/s41300-019-00072-8}

The article was published under the incorrect title "University of Oklahoma". The title has now been corrected to "The interaction of crime \& place: an exploratory study of crime \& policing in non-metropolitan areas".

Publisher's Note Springer Nature remains neutral with regard to jurisdictional claims in published maps and institutional affiliations.

The original article can be found online at https://doi.org/10.1057/s41300-019-00072-8.

Rashi K. Shukla

rshukla@uco.edu

1 University of Central Oklahoma, School of Criminal Justice, 100 N. University Drive, Edmond, OK 73034, USA

2 Department of Sociology and Anthropology, West Virginia University, 307 Knapp Hall, PO Box 6326, Morgantown, WV 26506, USA 